\title{
Effect of starvation on the type and distribution of mucus cells in the digestive tract of the yellow drum Nibea albiflora (Richardson, 1846)
}

\author{
ZHOU ZHOU ${ }^{1}$, BAO LOU ${ }^{2}$, BAOGUI XUE ${ }^{2}$, YANG XING ${ }^{1}$, HUILAI SHI ${ }^{2}$ AND DONGDONG XU ${ }^{2}$ \\ ${ }^{1}$ Fisheries Research Institute of Guizhou Province, No. 2448, South Section, Huaxi Avenue, Guiyang City, 550025 \\ Guizhou, China \\ ${ }^{2}$ Key Lab of Mariculture and Enhancement, Marine Fishery Institute of Zhejiang Province, 25 Xiaoxihu Road \\ Zhoushan - 316100, Zhejiang, China \\ e-mail:xbgmyfuture@126.com
}

\begin{abstract}
Effects of starvation on the type and distribution of mucus cells in the digestive tract of Nibea albiflora were evaluated by Alcian Blue/Periodic acid-Schiffs staining (AB-PAS). The experimental fishes were divided into four groups. Control group (S0) was fed with formulated diets to satiation twice a day during the experiment. The other three groups were deprived of feed for 10 (S10), 20 (S20), and 30 (S30) days. Results showed that the total number of mucus cells in the oropharyngeal cavity decreased significantly during the experiment, while no significant differences were observed in the hindgut. In S10 fishes, mucus cells in oesophagus decreased initially and then stabilised, whereas the total number of mucus cells in the foregut decreased significantly $(p<0.05)$. Type I, II and IV mucus cells significantly decreased in all parts of the digestive tract of starved fishes $(p<0.05)$. Type IV mucus cells were the most severely affected cells which even disappeared in the digestive tract after ten days of starvation. However, type III mucus cells containing mainly neutral substances increased significantly during starvation stress $(\mathrm{p}<0.05)$.
\end{abstract}

Keywords: Digestive tract, Mucus cells, Nibea albiflora, Starvation

Mucus in fish has a wide range of functions related to feeding, excretion, reproduction, respiration, ionic and osmotic regulation, protection from/resistance to diseases (Hoste, 2001; Smirnova et al., 2003; Ringo et al., 2007; Yan et al., 2007; Schroers et al., 2009). Mucus cells produce glycosylated proteins called mucins and they would be influenced by endogenous factors including sex and developmental stage, as well as exogenous factors such as salinity and low temperature (Franklin, 1990; Borsa et al., 2003; Elliott and Elliott, 2010). Moreover, variations in the number of mucus cells and dimension in digestive tract could be an indicator of pathological or inflammatory processes under adverse environmental conditions (Ortiz et al., 1999; Hideya and Tatsuya, 2013).

Food availability tends to widely fluctuate in many aquatic environments. As a consequence, many aquatic animals, including fish, generally experience long periods of starvation. It is well known that the intestinal mucosa appears to be dynamic and highly responsive to food availability. Previous reports suggested that cell degeneration in digestive organs could be the best indicator for identifying starvation. The digestive tract atrophy may result from food deprivation or flourish from food abundance (Mcleese and Moon, 1989; Wang et al., 2006).
Previous studies mainly focused on the function of mucus cells and there are only few studies that reveal the variations in type and distribution of mucus cells during starvation. In this study, the type of mucus cells and their distribution in the alimentary canal of adult Nibea albiflora under starvation were analysed. The study was thus aimed to evaluate the response capacity of this fish species, as well as the degree of alterations due to starvation.

The experiment was carried out during 2 September to 3 October 2011 in the Xishan testing ground of the Marine Fisheries Research Institute of Zhejiang Province. One year old fishes of $N$. albiflora were obtained from the same batch of fertilized eggs.

A total of 225 fishes (average weight $120 \pm 8.0 \mathrm{~kg}$ ) were transferred to 15 circular fiberglass tanks (water volume 250 1), with 15 fishes per tank. These fishes were acclimated to the laboratory conditions for two weeks. During this period, they were fed twice daily with commercial formulated diet (Tech-Bank). The experiment was conducted for one month and comprised of four treatments and a control, with three replicates for each of the treatments as well as for the control. The experimental treatments were based on the period of starvation viz., starvation period of $0 \mathrm{~d}$ (S0), 10d (S10), 20d (S20) and 30d (S30). The fish in control group was fed twice a 
day throughout the experiment, with no starvation stress. About $80 \%$ of the water in each tank was replaced daily to avoid the accumulation of waste products. During the experiment, water quality parameters were maintained at optimum levels i.e., water temperature at $22 \pm 2^{\circ} \mathrm{C}, \mathrm{pH}$ at 7.5 , dissolved oxygen level $>5 \mathrm{mg} \mathrm{l}^{-1}$, ammonia-nitrogen $<0.02 \mathrm{mg} \mathrm{l}^{-1}$ and the nitrite level $<0.01 \mathrm{mg} \mathrm{l}^{-1}$. The fishes were held under natural photoperiod condition throughout the feeding trial.

For each sampling, ten fish from each tank were randomly chosen. The entire digestive tract was removed and carefully cleaned. The digestive tract was divided into oropharyngeal cavity, oesophagus, stomach, foregut, midgut and hindgut. Pieces of each part of the digestive tract were excised and fixed in Bouin's aqueous solution for $24 \mathrm{~h}$ for histological studies. The samples were then processed, embedded in paraffin wax following standard procedures. Sections of $6 \mu \mathrm{m}$ were cut from each block and then stained with Alcian Blue/Periodic Acid-Schiff (AB-PAS, pH 2.6) (Jones and Reid, 1973). Representative tissue sections from fish of different treatment groups (S0, S10, S20 and S30) were observed under microscope at $200 \times$ magnification. For each section, the type and distribution of mucus cells in an area of $0.01 \mathrm{~mm}^{2}$ were analysed with NIKON Eclipse 50i software. The data were shown as mean \pm SD. One-way ANOVA followed by Duncan's multiple range test was performed to determine differences among S0, S10, S20 and S30, using SPSS 16.0 for Windows.

The type and distribution of mucus cells in the digestive tract were analysed by examining the AB-PAS stained sections under microscope. Based on the data, mucus cells of tissues could be divided into four types. PAS positive and $A B$ negative cells which stained red were classified as Type I cells and contained neutral mucopolysaccharides. PAS negative and $\mathrm{AB}$ positive Type II cells which stained blue contained acidic substances. Type III cells which stained purple red had more proportion of PAS positive than AB. Type III cells secreted mixed mucopolysaccharides with more neutral than acidic components. Type IV cells stained in blue purple had more proportion of positive AB than PAS and produced more acidic mucopolysaccharides.

There was a significant reduction in total number of mucus cells in the oropharyngeal cavity after starvation $(p<0.05)$ (Table 1). A significant increase was found in the amount of type I cells in S10 fish compared with that of S0 fish. The quantity of type I cells was stable in S20 fish, but was found to be at the lowest level in S30. Nevertheless, a steep decrease of type II cells was observed after starvation and has even disappeared in oropharyngeal cavity of S20 fish $(\mathrm{p}<0.05)$. In addition, the number of type III cells decreased notably to the lowest level in S20 fish and elevated significantly in S30 fish $(p<0.05)$. Furthermore, the amount of type IV cells showed a descending trend after starvation and its lowest level was found in S30 fish ( $\mathrm{p}<0.05)$ (Fig. 1).

A significant decrease of total number of mucus cells in stomach was observed and it ranged from $596.48 \pm 121.13$ (S0) to $371.93 \pm 64.25$ (S20) (Table 1). The mucus cells of type I and type II in stomach exhibited a similar trend wherein the cells decreased significantly in S10 and disappeared from S10 to S30. In addition, type III cells of stomach in S10 fish increased enormously, but declined gradually in $\mathrm{S} 20$ ( $\mathrm{p}>0.05)$. It would be stabilised at a higher level than that of the initial values in S30 fish. The number of type IV cells decreased notably to the lowest level in S30 fish (Fig. 1).

In the foregut of S10 fish, there was a reduction of mucus cells and the reduction was significantly lower than other groups (231.57 \pm 45.39$)$ (Table 1). Type I cells in the foregut decreased significantly and even disappeared in $\mathrm{S} 30$ fish $(\mathrm{p}<0.05)$. The starvation would affect type II as well as type IV mucus cells in foregut and it was found that the quantity of these cells decreased significantly and disappeared in the foregut of S10 fish. Furthermore, the amount of type III cells in the foregut kept rising during the experiment (Fig. 1).

No significant difference was observed for total amount of mucus cells in the midgut in S0 and S10 fish ( $p>0.05$ ). However, mucus cells in S0 decreased significantly from S20 and S30 (Table 1). The number of type I cells decreased steeply after starvation and it even

Table 1. Effect of starvation on total number of mucus cells

\begin{tabular}{lllll}
\hline Distribution & \multicolumn{4}{c}{ Total number of mucus cells (Mean+SD) } \\
\cline { 2 - 5 } & \multicolumn{1}{c}{ 0d } & $10 \mathrm{~d}$ & $20 \mathrm{~d}$ & $30 \mathrm{~d}$ \\
\hline Oropharyngeal cavity & $1070.24 \pm 328.95^{\mathrm{a}}$ & $728.28 \pm 112.47^{\mathrm{b}}$ & $561.4 \pm 86.21^{\mathrm{c}}$ & $429.81 \pm 82.47^{\mathrm{d}}$ \\
Oesophagus & $421.05 \pm 95.78^{\mathrm{a}}$ & $329.82 \pm 69.01^{\mathrm{b}}$ & $284.21 \pm 53.24^{\mathrm{b}}$ & $301.65 \pm 51.96^{\mathrm{b}}$ \\
Stomach & $596.48 \pm 121.13^{\mathrm{a}}$ & $456.14 \pm 90.20^{\mathrm{b}}$ & $371.93 \pm 64.25^{\mathrm{c}}$ & $358.74 \pm 55.20^{\mathrm{c}}$ \\
Foregut & $489.47 \pm 89.53^{\mathrm{a}}$ & $231.57 \pm 45.39^{\mathrm{b}}$ & $428.06 \pm 60.14^{\mathrm{a}}$ & $461.87 \pm 63.27^{\mathrm{a}}$ \\
Midgut & $545.61 \pm 127.41^{\mathrm{a}}$ & $508.78 \pm 75.47^{\mathrm{a}}$ & $438.63 \pm 68.02^{\mathrm{b}}$ & $419.77 \pm 71.28^{\mathrm{b}}$ \\
Hindgut & $519.34 \pm 108.48^{\mathrm{a}}$ & $600.02 \pm 76.82^{\mathrm{a}}$ & $566.37 \pm 66.10^{\mathrm{a}}$ & $543.85 \pm 86.37^{\mathrm{a}}$ \\
\hline
\end{tabular}

Means in a column with the same superscript letters are not significantly different $(\mathrm{p}>0.05)$ 


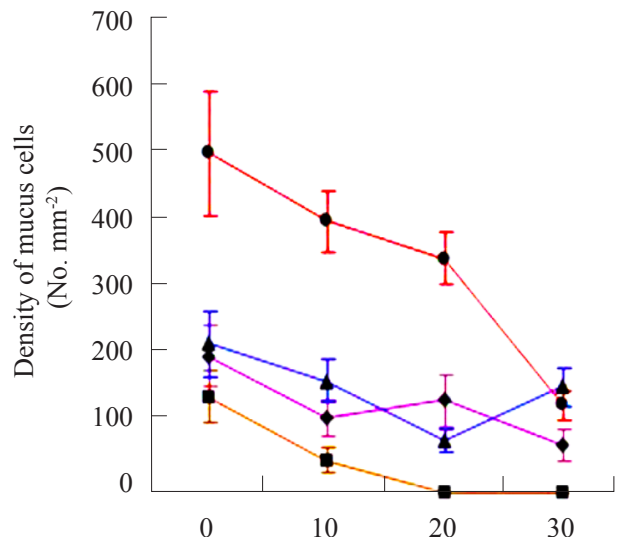

(a)

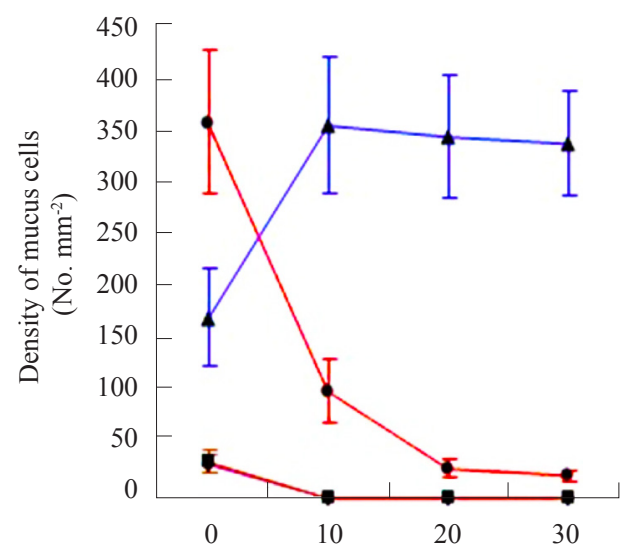

(c)

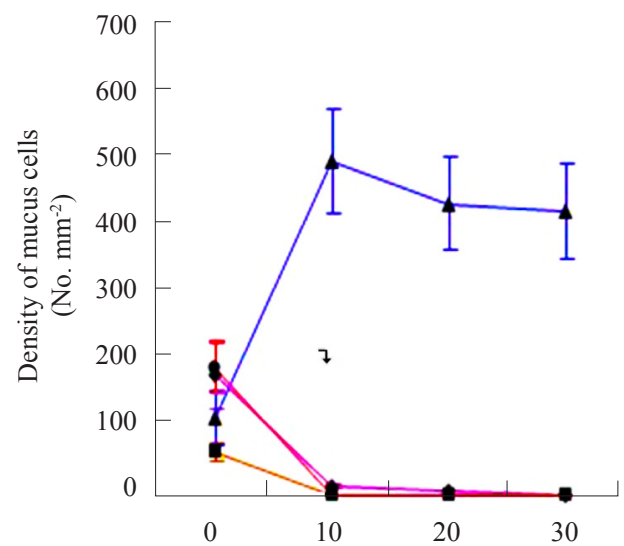

(e)

Starvation time

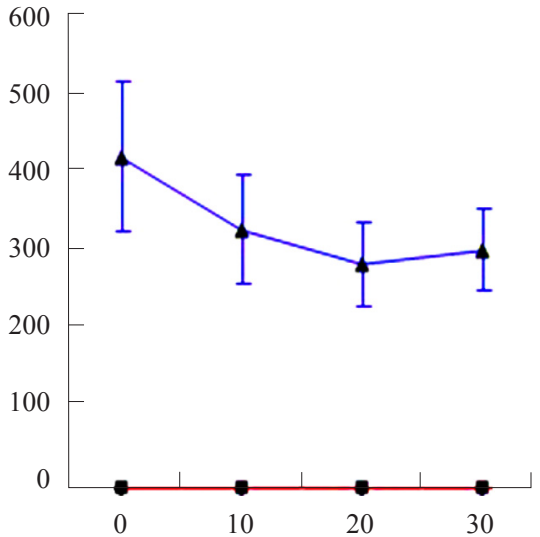

(b)

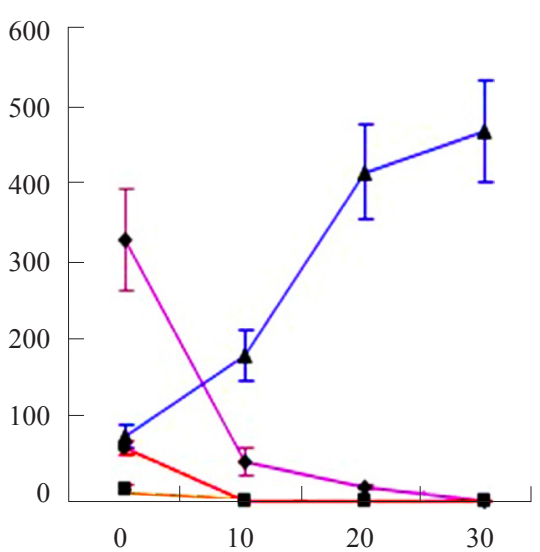

(d)

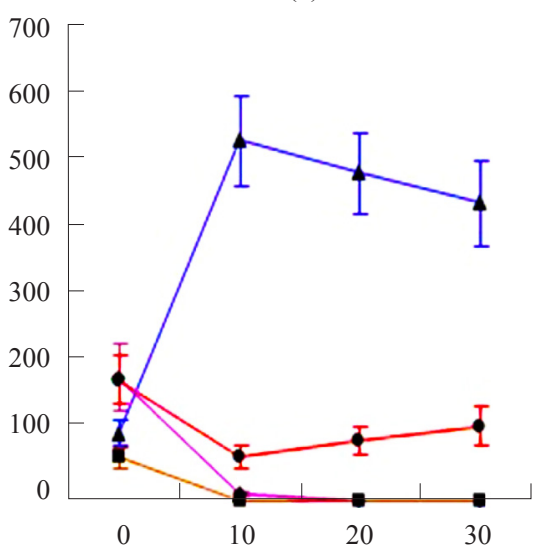

(f)

$\leadsto$ Type I, $\longrightarrow$ Type II, $\longrightarrow$ Type III, $\longrightarrow$ Type IV

Fig. 1. Effect of starvation on diffrent types of mucus cells in the digestive tract of N. albiflora. (a) Oropharyngeal cavity, (b) Oesophagus, (c)Stomach, (d) Foregut, (e) Midgut, (f) Hindgut.

disappeared in midgut of S30 fish. Type II as well as type IV cells decreased significantly and finally disappeared in S10 fish. The number of type III cells elevated by 4.1 times $(p<0.05)$ compared to that of S0 fish and decreased slightly in midgut of S20 and S30 fish ( $>>0.05)$ (Fig. 1).
No significant differences were observed in total amount of mucus cells in the hindgut. Type I cells decreased significantly after starvation $(p<0.05)$ and it even disappeared in S20 group. Type II cells also showed a descending trend after starvation. Type III cells in S10 fish increased significantly compared to that of S0 fish and 
showed a slight decrease in $\mathrm{S} 20$ and $\mathrm{S} 30(\mathrm{p}<0.05)$. Finally, it rebounded and kept increasing in S20 and S30 fish (Fig. 2).

Alcian Blue/Periodic Acid-Schiff (AB-PAS) staining is used as a specific staining for mucus cells and it is possible to identify the concentrations of acidic and neutral mucus glycoproteins by the intensity of staining. The different types of mucus cells are classified as acidic and neutral mucus glycoproteins based on AB-PAS staining (Wang et al, 2003; Cinar et al., 2008; Kumari et al., 2009). Therefore, mucus cells in the digestive tract of $N$. albiflora were separated and analysed with AB-PAS

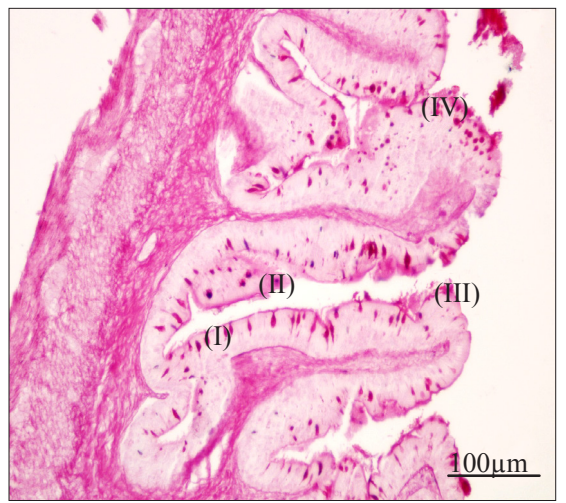

(a)

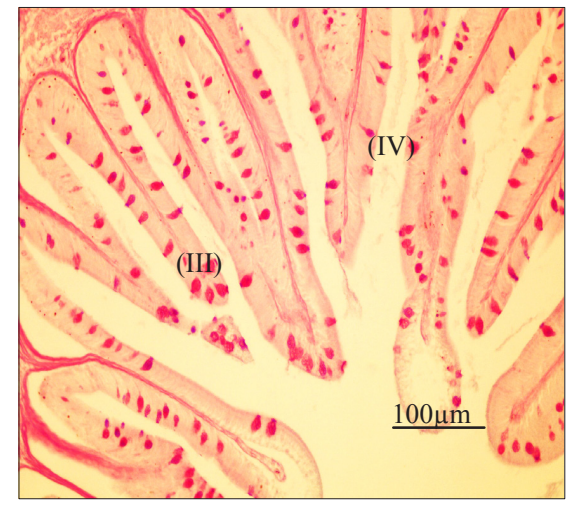

(c) cells was observed in all parts of the digestive tract except for oesophagus. The transformation of mucus cell types after starvation may be closely related to their functions. The type II and IV cells mainly take part in metabolising acidic substances. The quantitative decrease of type II and IV cells reflected a reduction in defense capacity against bacterial invasion by mucus (Zimmer et al., 1992).

Furthermore, it has been reported that neutral glycol-conjugates secreted by mucus cells would be involved in enzymatic digestion of food and absorptive functions in other regions of alimentary canal (Grau et al., 1992; Murray et al., 1996). The secretion of neutral

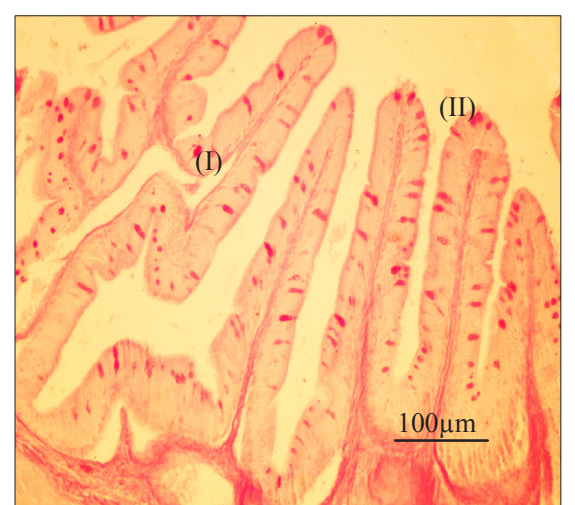

(b)

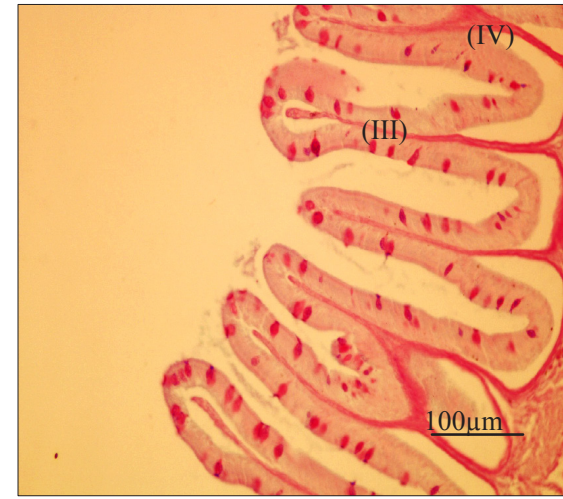

(d)

Fig. 2. Effect of starvation on mucus cells in the hindgut of Nibea albiflora (AB-PAS; $\times 200$ ). (a) S0, (b) SI0, (c) S20, (d) S30 I : Type I cells, II : Type II cells, III : Type III cells, IV : Type IV cells

staining in this study. It has been reported that the quantity and morphology of mucus cells, as well as other cells localised in the epithelium of digestive tract, would be affected by various factors (Franklin, 1990; Borsa et al., 2003; Elliott and Elliott, 2010). The quality and quantity in variation of mucus cells has been reported as a defensive signal against invading organisms. In this study, our results showed that the amount of type I, II and IV cells significantly decreased in the digestive tract of $N$. albiflora under starvation, whereas a notable increase in type III glycol-conjugates containing sugar residues by mucus cells has been validated in gastric glands of various fish species (Gisbert et al., 1999; Sarasquete et al., 2001; Diaz et al., 2008). Neutral glyco-conjugates could play a critical role in protecting the epithelium of stomach from auto-digestion processes. The auto-digestion may result from high concentration of $\mathrm{HCl}$ and enzymes produced in gastric glands (Ferraris et al., 1987). Therefore, it was concluded that the increase in quantity of type III cells could be an active response to starvation in N. albiflora. 
Mucus cells and the mucin produced, are indicators of immune status of fish, and play an important role in non-specific immune response. Previous reports demonstrated that immunoglobulin of mucus were similar to that of plasma, based on immuno-electrophoretic analysis (Yang et al., 1998). Another study suggested an assessment system for immunogenic substances by checking the density variation of mucus cells in gills of carp (Zhu, 2000). In the present study, the effects of starvation on type I cells were found to be notably different in digestive tract and it could not be observed in stomach (S10), midgut (S20) and the hindgut (S30 fish). As a result, the distribution of type I mucus cells could be considered as an indicator for estimating starvation stress.

The total amount of mucus cells varied under different starvation conditions in each part of the digestive tract (Table 1). This result was in accordance with that of previous reports, which demonstrated that different mucus substances would be secreted by mucus cells from different regions in the digestive tract. It would also vary with species (Reid et al., 1990; Cinar and Senol, 2006).

During the present study, the total amount of mucus cells reached $1070.24 \pm 195.87$ (per $\mathrm{mm}^{2}$ ) in the oropharyngeal cavity of control group. The amount was significantly larger than other parts of the digestive tract. The effects of starvation on mucus cells in the oropharyngeal cavity was also greater than in other parts. The total number of mucus cells in hindgut slightly varied during the experiment (Fig. 2). In Cyprinus carpio, the oropharyngeal cavity was found to play a major role in protection from bacterial infection and mechanical damage, in addition to serving as a buffer resisting the high acidity of the stomach (Sibbing and Uribe, 1985). Maximum number of mucus cells were found in oropharyngeal cavity which indicated the importance of this part of digestive tract. The decrease of mucus cells in oropharyngeal cavity suggested that the functions of bacterial inhibition and digestion were gradually forfeited by starvation.

In the present study, although the effects of starvation on mucus cells have been observed, the underlying functional mechanism is not clearly discernible. Future studies should attempt in this line and also need to attempt to investigate if the mucus cells could be renewed by refeeding after starvation.

\section{Acknowledgements}

This work was supported by grants from the Project of Zhejiang Province of China (No. 2009C12081 and No. 2010F20006).

\section{References}

Borsa, M. A., Balebona, M. C., Chabrillon, M., Rodriguez Maroto, J. M. and Morinigo, M. A. 2003. Influence of temperature and salinity on the adhesion of pathogenic strains of Vibrio alginolyticus and Listonella anguillarum to mucus surface of gilt-head seabream (Sparus aurata L.). Bull Eur. Ass. Fish. Pathol., 23: 273-280.

Cinar, K., Senol, N. and Ozen, M. R. 2008. Histochemical characterisation of glycoproteins in the gills of the carp (Cyprinus carpio), Ankara Univ. Vet. Fak. Derg., 55: 61-64.

Cinar, K. and Senol, N. 2006. Histological and histochemical characterisation of the mucosa of the digestive tract in flower fish (Pseudophoxinus antalyae). Anat. Histol. Embryol., 35: 147-151.

Diaz, A. O., Garcia, A. M. and Goldemberg, A. L. 2008. Glycoconjugates in the mucosa of the digestive tract of Cynoscion guatucupa: a histochemical study. Acta Histochem., 110(1): 76-85.

Elliott, J. M. and Elliott, J. A. 2010. Temperature requirements of Atlantic salmon Salmo salar, brown trout Salmo trutta and Arctic charr Salvelinus alpinus: predicting the effects of climate change. J. Fish. Biol., 77(8): 1793-817.

Ferraris, R. P., Tan, J. D. and De La Cruz, M. C. 1987. Development of the digestive tract of milkfish, Chanos chanos: Histology and histochemistry. Aquaculture, 61: 241-257.

Franklin, G. C. 1990. Surface ultrastructural changes in the gills of sockeye salmon (Teleostei: Oncorhynhus nerka) during seawater transfer: comparison of successful seawater adaptation. $J$ Morphol., 206: 13-23.

Gisbert, E., Sarasquete, M. C., Williot, P. and Castello-Oravy, F. 1999. Histochemistry of the development of the digestive system of Siberian sturgeon during early ontogeny. J. Fish Biol., 55: 596-616.

Grau, A., Crespo, S., Sarasquete, M. C. and Gonzalez De Canales, M. L. 1992. The digestive tract of the amberjack, Seriola dumerili, Risso: A light and scanning electron microscope study. J. Fish Biol., 41: 287-303.

Hideya, T. and Tatsuya, S. 2013. The role of 'mineralocorticoids' in teleost fish: Relative importance of glucocorticoid signaling in the osmoregulation and 'central' actions of mineralocorticoid receptor. Gen. Comp. Endocr., 181: 223-228.

Hoste, H. 2001. Adaptive physiological process in the host during gastrointestinal parasitism. Int. J. Parasitol., 31: 231-244.

Jones, R. and Reid, L. 1973. The effect of $\mathrm{pH}$ on Alcian blue staining of epithelial and glycoproteins. Hist. J., 5: 7-9.

Kumari, U., Yashpal, M. and Mitta, S. 2009. Histochemical analysis of glycoconjugates in the secretory cells in the gill epithelium of a catfish, Rita rita (Siluriformes, Bagridae). Tissue Cell, 41(4): 271-280. 
Mcleese, J. M. and Moon, T. W. 1989. Seasonal changes in the intestinal mucosa for winter flounder, Pseudopleuronectes americanus (Walbaum), from Passamaquoddy Bay, New Brunswick. J. Fish Biol., 35: 381-393.

Murray, H. M., Wright, G. M., and Goff, G. P. 1996. A comparative histological and histochemical study of the post-gastric alimentary canal from three species of pleuronectid, the Altantic hailbut, the yellowtail flounder and the winter flounder. J. Fish Biol., 48: 187-206.

Ortiz, J. B., Gonzalez De Canales, M. L. and Sarasquete, C. 1999. Quantification and histopathological alterations produced by sublethal concentrations of copper in Fundulus heteroclitus and Ciencias Marinas, 25(1): 119-143.

Reid, P. E., Owen, D. A., Magee, F. and Park, C. M. 1990. Histochemical studies of intestinal epithelial goblet cell glycoproteins during the development of the human foetus. Histochem. J., 22(2): 81-86.

Ringo, E., Myklebust, R., Mayhew, T. M. and Olsen, R. E. 2007. Bacterial translocation and pathogenesis in the digestive tract of larvae and fry. Aquaculture, 268: 251-264.

Sarasquete, C., Gisbert, E., Ribeiro, L., Vieira, L. and Dinis, M.T. 2001. Glycoconjugates in epidermal, branchial and digestive mucus cells and gastric glands of gilthead seabream, Sparus aurata, Senegal sole, Solea senegalensis and Siberian sturgeon, Acipenser baeri development. Eur. J. Histochem., 45(3): 267-78.

Schroers, V., van der Marel, M., Neuhaus, H. and Steinhagen, D. 2009. Changes of intestinal mucus glycoproteins after preoral application of Aeromonas hydrophila to common carp (Cyprinus carpio). Aquaculture, 288: 184-189.

Sibbing, F. A. and Uribe, R. 1985. Regional specialisations in the oro-pharyngeal wall and food processing in the carp (Cyprinus carpio L.). Netherl. J. Zool., 35(3): 377-422.

Smirnova, M. G., Guo, L., Birchall, J. P. and Pearson, J. P. 2003. LPS-up-regulates mucin and cytokine mRNA expression and stimulates mucin and cytokine secretion in goblet cells. Cell Immunol., 221: 42-49.

Wang, Y. Y., Sun, H. S. and Sun, X. Q. 2003. Type and distribution of mucus cells in the digestive system of scallop Argopecten irradians. J. Fishery Sci. China, 10(3): 254-256.

Wang, T., Hung, C. and Randal, D. J. 2006. The comparative physiology of food deprivation: from feast to famine. Annu. Rev. Physiol., 68: 223-251.

Yan, Q., Chen, Q., Ma, S., Zhuang, Z. and Wang, X. 2007. Characteristics of adherence of pathogenic Vibrio alginolyticus to the intestinal mucus of large yellow croaker (Pseudosciaena crocea). Aquaculture, 269: 21-30.

Yang, G. W., An, L. G. and Wang, C. F. 1998. Comparative studies on the immunoglobulin in skin mucus and serum of carp. Zool. Res., 19(6): 489-492.

Zhu, Q. Z. 2000. The effect of Con A on mucus cells of carp. Chinese J. Zool., 35(1): 10-12.

Zimmer, G., Reuter, G. and Schauer, R. 1992. Use of influenza c-virus for detection of acetylated sialic acids on immobilised conjugates by esterase activity. Eur. J. Biochem., 204: 209-215.

Date of Receipt : 02.07.2013

Date of Acceptance : 20.05.2016 